\title{
Relationship Response Time Handling Stroke Patients With Anxiety of Patients Family in Emergency Room
}

\author{
Hendratmo Lasaka, Alfian Fawzi, Aprin Rusmawati, Agusta Dian Ellina* \\ Institute of Health Science STRADA Indonesia, East Java Indonesia \\ Corresponding author: agustadian85@gmail.com
}

\begin{abstract}
Background: Response time that is done to stroke patients when taken to hospital causes anxiety problem for the patient's family, this is due to family concerns about the health condition of family members who are waiting for the queue of action.

Purpose: This study aimed to know the relationship response time of stroke patients with anxiety in the patient's family in the Emergency Room.

Method: This research design was a correlational analytic with cross sectional approach. The population were all families of stroke patients in the Emergency Room of Luwuk Regional Hospital averagely 35 patients per month, with accidental sampling technique obtained sampleas many as 33 respondents. The independent variable was Response time with the dependent variable Anxiety. Data collection using a questionnaire. Data analysis using Spearman Rank test on $\alpha=0.05$.

Result:The results showed that most respondents received response time in the right category, as many as 21 respondents (63.6\%) and most respondents had an anxiety level in the moderate category, as many as 17 respondents (51.5\%).analysis results Spearman Rank obtained $p$-value $(0,000)<\alpha(0.05)$ then $\mathrm{H} 0$ is rejected and $\mathrm{H} 1$ is accepted, which means there is a relationship between response time handling of stroke patients with anxiety in the patient's family in the Emergency Room

Conclution: The role of nurses is crucial in raising anxiety level in both patients and their families while in the emergency room. Fast and appropriate services and no less important communication with the family is an important factor in providing certainty and educating in handling patients while in the emergency room so that families are not too worried about the situation that is happening.
\end{abstract}

Keywords: Response Time, Stroke Patients, Anxiety.

Received July, 29, 2019; Revised August 30, 2019; Accepted September 22, 2019

How to Cite: Lasaka, H., Fawzi, A., Rusmawati, A., \& Ellina, A.D. (2019). Relationship Response Time Handling Stroke Patients With Anxiety of Patients Family in Emergency Room. Journal Of Nursing Practice, 3(1), 87-95. https://doi.org/10.30994/jnp.v3i1.69 


\section{BACKGROUND}

Stroke is a condition in which brain dysfunction occurs due to blood supply to the brain experiencing problems that occur suddenly (fast), and last for 24 hours so that biochemical reactions occur that cause cells in the brain to become dead (Wiwit, 2010). According to thedefinition World Health Organization (WHO), stroke is a clinical sign that develops rapidly due to focal (or global) brain disorders with symptoms that last for 24 hours or more and can cause death without any other obvious cause other than vascular (Harsono, 2009). To minimize the risk of brain damage, response time is the most important factor in early stroke management.

The time period for handling a stroke is 3 hours from the the initial symptoms, more than three hour period is too dangerous for action. The part of the brain that does not get blood intake becomes damaged, if forced to take action to launch a blockage it is very risky to cause more severe bleeding in the brain (Persistent, 2012). Response time that is done to stroke patients when brought to the hospital raises its own anxiety problem for the patient's family, this is due to family concerns about the health condition of family members who are waiting for the queue of action (Tumbuan, 2015). The phenomenon that often occurs related to response time is the patient's family does not know the problem of Triage in the emergency room so that the patient's family sometimes thinks that the treatment is not fast and can cause anxiety for his family's critical health. Anxiety itself is related to underlying health problems for a large number of people, in some cases anxiety is the first sign and symptom or indicator that someone has a medical disease (Musliha, 2015)

In 2017 data from the World Health Organization (WHO) shows as many as 15.1 million per year worldwide have a stroke (WHO, 2017). The Indonesian Stroke Foundation (Yastroki, 2017) states that Indonesia in 2017 was the country with the largest number of stroke sufferers in Asia, reaching 3.3 million people consisting of new and old sufferers. In Indonesia stroke is the number three deadly disease after heart disease and cancer. About $3.85 \%$ of elderly people have a stroke and $12.9 \%$ at a younger age. Every year an estimated 500 thousand people in Indonesia suffer a stroke. Of this amount, one third can recover, another third have mild to moderate functional impairment, and the remaining third have severe functional impairment which requires the sufferer to continue lying in bed. According to Pambudi (2008), 78\% of families of stroke patients experience anxiety related to the patient's health condition.

The results of a preliminary study conducted on February 14, 2018 in the Emergency Room of Luwuk Regional Hospital are known to have an average number of 31 stroke patients per month. Observations made on 5 stroke patients known response time in 3 patients about 5 minutes, when an interview with the patient's family obtained answers that 2 of 3 family members said they were worried about the patient's condition because when they arrived the patient still had to wait, for them time 5 minutes was very long, while 1 other family member of the patient said he was grateful because the patient had been treated with not too long to wait even though he had been nervous and had cold sweat waiting for the patient to be treated. The other 2 stroke patients received response time within 12 minutes and 15 minutes, when asked about the feelings of the family obtained information that the two families who delivered the patient claimed to be very anxious even one of the families had to go back and forth to the toilet because of panic queues at the ER long. 


\section{Journal Of Nursing Practice}

http://thejnp.org

ISSN: 2614-3488 (print); 2614-3496 (online)

Vol.3 No.1. October 2019. Page.87-95

Stroke occurs when blood flow to the brain is disrupted. The disorder causes the blood supply to the brain decrease or stop. The human brain need of blood supply, because in the blood there are nutrients and oxygen for the brain. The brain that does not get blood supply will have an impact on paralysis so that it burdens the family but can also cause death. (Wardhana, 2011). The condition of stroke patients who are not treated immediately can encourage damage to the brain resulting in decreased functional organ of the motion causing disruption in carrying out the daily activities of patients, even in some cases causing dependence, this has an impact on the emergence of anxiety in the family of stroke patients associated with patient recovery and the emergence of additional burdens on the family (Ritarwan, 2013).

The phenomenon that often occurs in emergency rooms related to response time is patient and family anxiety about emergency treatment. Because most patients do not know about the problem Triage in the emergency room so the patient's family sometimes thinks that the handling is not fast, causing anxiety for the health of family members (Putri, 2016). The level of anxiety in the patient's family is not only influenced by the response time of nurse, but seen from the patient's worrisome condition so that the family still feels anxious and the lack of knowledge in the patient's family about emergency treatment makes the family more anxious.

The success of response time is very dependent on the speed available and the quality of assistance to save lives or prevent defects from the scene, on the way to hospital help (Hasan, 2012). Many post-stroke sufferers become disabled enough to cause disruption in their activities if not treated immediately. This condition raises anxiety for his family because of the uncertainty of the future of this patient himself especially if the patient does not immediately get treatment (Pudiastuti, 2011).

Nurses in carrying out the nursing process in stroke patients tend to only focus on patients and pay less attention to the family even though the family has an important role to help the nursing process, so nurses need to help prevent anxiety in the family by providing information that can be understood by the family. According to Festy (2012), nurses need to involve the family in the initial care process of stroke patients so that the family is able to support the implementation of care measures properly.

\section{OBJECTIVES}

This study aimed to know the relationship between response time handling stroke patients with anxiety in the patient's family in the Emergency Room of Luwuk Regional Hospital

\section{METHODS}

\section{Design}

Design of research used in this research was correlation analytic research which is a research that aims to find out the relationship between two or more variables with the process of data retrieval that only done once for each research variable (Notoatmodjo, 2009). The approach used is cross sectional research that is independent variables and the dependent variable is measured simultaneously and carried out briefly or once (Nursalam, 2008). 


\section{Population, Sample and Sampling}

The population in this study were all families of stroke patients in the Emergency Room of Luwuk Regional Hospital. Using an accidental sampling technique as many as 33 respondents was obtained.

\section{Research}

Variables The independent variable in this study was Response time, while the dependent variable was anxiety. The instrument used in this study is the observation sheet and questionnaire which is the type of primary data

\section{Data Analysis}

The statistical test used in this study is Spearman rank test a level of deviation of $5 \%$ $(\alpha=0.05)$.

\section{Ethical considerations}

The participants were assured that their engagement was voluntary, and that anonymity, privacy, and confidentiality of the data were guaranteed. Furthermore, they were informed about the purpose and the method of the study before signing a written informed consent. The questionnaires were distributed to eligible participants at the Luwuk Regional Hospital, and respondents were asked to complete and return them in the same time.

\section{RESULTS}

\section{Response time for stroke patients in the Emergency Room of Luwuk Hospital.} as follows:

Response time treating patients with stroke in Luwuk Hospital emergency room are

Tabel 1 VariableCharacteristics of Response Time HandlingStroke Patients in hospitals emergency room Luwuk May 9 - June 9, 2018

\begin{tabular}{cccc}
\hline No & Response Time & & Frequency\% \\
\hline 1 & Exactly & 21 & 63.6 \\
2 & Notright & 12 & 36,4 \\
\hline \multicolumn{2}{c}{ Total } & 33 & $100.0 \%$ \\
\hline
\end{tabular}

Based on table 4.1 it is known that most respondents get response time the appropriate category, which is 21 respondents (63.6\%).

Anxiety in the family of stroke patients in the Emergency Room of Luwuk Hospital.

Anxiety in stroke family in Luwuk Hospital Emergency Room is as follows:

Tabel 2 Variable Characteristics of Anxiety in Stroke Patient Family in Luwuk Hospital Emergency Room May 9 - June 92018

\begin{tabular}{clcc}
\hline No & \multicolumn{1}{c}{ Anxiety } & Frequency & $\%$ \\
\hline 1 & Normal & 0 & 0.0 \\
2 & Mild & 14 & 42.4 \\
3 & Moderate & 17 & 51.5 \\
4 & Weight & 2 & 6.1 \\
\hline \multicolumn{2}{r}{ Total } & 33 & $100.0 \%$ \\
\hline
\end{tabular}




\section{Journal Of Nursing Practice}

http://thejnp.org

ISSN: 2614-3488 (print); 2614-3496 (online)

Vol.3 No.1. October 2019. Page.87-95

Based on table 4.2 it is known that the majority of respondents have an anxiety level in the moderate category, namely 17 respondents $(51.5 \%)$.

\section{DATA ANALYSIS}

Hypothesis testing is done using thecorrelation test Spearman rank obtained the following:

Tabel 1 resultsAnalysis Results of Relationship Response Time Handling of Stroke Patients With Anxiety in Patients' Families in the Emergency Room of Luwuk Regional General Hospital May 9 - June 92018

\begin{tabular}{lll}
\hline Variable & Correlation Coefficient & Sig. (2-tailed) \\
\hline Response Time - Anxiety & $0.678^{* *}$ & 0,000 \\
\hline $\mathrm{N}$ & 33 & 33 \\
\hline
\end{tabular}

The results of the analysis using thetest Spearman Rank show $p$-value $=0,000<<=$ 0.05 then $\mathrm{H} 0$ is rejected and $\mathrm{H} 1$ is accepted, which means there is a relationship between response time handling stroke patients with anxiety for patients' families in Luwuk Regional Hospital Emergency Room. Based on the correlation coefficient of 0.678, it can be interpreted that the closeness of the relationship between the variable Response Time Handling Stroke Patients With Anxiety in the Family Patients in the strong category, $67.8 \%$ response time handling stroke patients associated with anxiety in the family received while the remaining $33.2 \%$ caused by other factors not examined in this study.

\section{DISCUSSION}

\section{A. Response time handling stroke patients in the Emergency Room of Luwuk Regional Hospital}

Response time handling of stroke patients in the Emergency Room of the Luwuk Regional Hospital is known that most patients get response time in the right category, namely 21 patients $(63.6 \%)$ and almost half of patients get a response time in the inappropriate category were 12 patients $(36.4 \%)$. Based on the characteristics of the respondents it is known that almost half of the respondents have basic education, namely 16 respondents (49\%).

Response Time is the speed in handling patients, calculated from the time the patient arrived until treatment was carried out (Suhartati et al. 2011). A good response time for patients is $\leq 5$ minutes. (Ministry of Health Republic of Indonesia, 2009). Service response time can be calculated in a matter of minutes and is greatly influenced by various matters both regarding the number of personnel and other supporting components such as laboratory, radiology, pharmacy and administration services. Response time is said to be on time or not late if the time required does not exceed the average standard time available (Haryatun and Sudaryanto, 2008). According to Long (2016) nursing intervention given in the emergency room to save lives is done when the patient's physiological state is threatened, such actions include giving emergency medication, performing cardiopulmonary resuscitation. A lifesaving medical treatment can bring anxiety, because there is a threat to bodily integrity (Araujo, 2014). 
The results showed that the majority of patients received response time in the right category, but the number of patients who received response time in the incorrect category was still quite a lot, the condition was at risk of reducing the success rate of healing in stroke patients. Time is a very important factor in the management of emergencies, it is important that therapy can follow a sequence in accordance with the order of urgency of the existing situation. The success of response time depends on the speed available and the quality of assistance to save lives or prevent severity.

The critical time for handling stroke patients, especially ischemic stroke is 3 hours since the attack occurred. Very short time is used to correct the blockage that occurs in the brain, but if more than 3 hours the patient has not received medical treatment, the patient will experience severe brain damage and result in extensive paralysis and cognitive impairment, there for is needed response time a fast possible to reduce the number of physical disabilities due to stroke.

Emergency management system in stroke patients in the ER is adjusted to the patient's condition which is divided into 4 zones. In general, the patient's family does not know the zone division system so that the handling system in the ER is in line with the queue of patients who enter. The triage system applied in the ER has gone through an appropriate selection so that the health and lives of patients can be saved. However, based on observations it can be seen that there are some patients who do not get response time in accordance with the provisions of the triage due to lack of medical staff and equipment in the ER and the large number of patients who are currently queuing to be immediately treated in the ER. Therefore, delivering clear information to the patient's family is important enough to prevent excessive anxiety in the family which can also have an impact on the decline in community satisfaction with the hospital.

\section{B. Anxiety in the family of stroke patients in the Emergency Room of Luwuk Regional Hospital}

Anxiety in the families of stroke patients in the Emergency Room of the Luwuk Regional Hospital is known that the majority of respondents have an anxiety level in the medium category, namely 17 respondents $(51.5 \%)$. Based on the cross tabulation it is known that respondents aged 36-45 years have anxiety levels in the mild category, which is 9 respondents $(27.3 \%)$.

Anxiety is an uncomfortable feeling or vague worry accompanied by an autonomic response (the source is often not specific or unknown to the individual); feelings of fear caused by anticipation of danger. This is a sign of vigilance that warns individuals of danger and enables individuals to act in the face of threats. (Nanda International, 2013). Anxiety itself is related to the underlying health problems for a large number of people, in some cases anxiety is the first sign and symptom or indicator that a person has a medical disease (Musliha, 2015). According to Yulishati (2011) emergency nursing services are services provided to patients to cope with emergency conditions and also provide nursing care to overcome anxiety in patients / families.

The results showed that the majority of patients' families experienced anxiety in the moderate category. Anxiety experienced by the patient's family in the emergency room is usually related to the patient's condition, the hope of recovery, and medical action to be given. Families also experience anxiety when they feel the service they 
are receiving is slow so that concerns arise if the patient's condition can worsen. Besides family anxiety can also arise due to lack of information received by the family from the hospital, especially related to the patient's condition and the priority system applied to the ER. A nurse who provides information about emergency response time to patients or the patient's family, will have a positive impact, one of which is the family can understand the patient's condition and procedures that must be carried out by the hospital so that it can provide certainty to the family about the time of handling patients in the end can reduce anxiety.

In terms of gender it is known that respondents with moderate anxiety tend to be more common in female respondents. Related to anxiety in men and women, women are more anxious about their disabilities compared to men. Men are more active and logical while women are more sensitive than men. They also tend to be able to think more rationally compared to women who have a tendency to think emotionally. Therefore, women are easier to feel anxious when getting stressor anxiety in Emergency room.

C. Relationship between response time handling of stroke patients with anxiety in the patient's family in the Emergency Room of Luwuk Regional Hospital.

The results showed that $p$-value $=0,000<<=0.05$ then $\mathrm{H} 0$ was rejected and $\mathrm{H} 1$ was accepted, which means there was a relationship between response time in handling stroke patients with anxiety in the patient's family in the emergency room of Luwuk Regional Hospital. Based on the correlation coefficient of 0.678, it can be interpreted that the closeness of the relationship between the variable Response Time Handling Stroke Patients With Anxiety in the Family Patients in the strong category, $67.8 \%$ response time handling stroke patients associated with anxiety in the family received while the remaining $33.2 \%$ caused by other factors not examined in this study.

Individuals that are classified as normal sometimes experience anxiety that appears, so that it can be witnessed in the appearance of physical and mental symptoms. Physical symptoms include cold fingers, faster heart rate, cold sweats, dizziness, decreased appetite, poor sleep, chest tightness. Mental symptoms are: fear of being overwritten by danger, unable to focus attention, not peaceful, wanting to escape from reality (Siti Sundari, 2014).

The results showed that there was a significant relationship between response time and family anxiety in stroke patients. Patients who come to the emergency room will experience a triage or priority selection process first. Patients will get services according to their conditions (green, yellow, red or black). The time spent by the family while waiting for patients to enter the emergency room is synonymous with boredom, anxiety, stress and even suffering. Reactions that can occur in anxious families include the release of cold sweat, trembling feelings of wanting to urinate over and over and running without a clear purpose.

The inappropriate response time of patients in the emergency room at the time of the study was due to the lack of nurses in the emergency room compared to the number of patients who came in, as well as several patients who arrived at the same time in the emergency department so nurses had to prioritize the most emergency problems. The inaccuracy caused the patient and family to have to wait longer to get treatment with uncomfortable conditions due to confusion and fatigue, causing 


\section{Journal Of Nursing Practice}

http://thejnp.org

increased family anxiety while waiting for treatment in the ER. This is supported by the results of cross tabulation which shows that patients who get response time the right category, families experience anxiety in the mild category.

Under these circumstances, the role of nurses is very important because in addition to having the main role in the emergency department, the role of nurses is crucial in the emergence of anxiety levels both in patients and their families while in the ER. Fast and appropriate services and no less important communication with the family is an important factor in providing certainty and educating in handling patients while in the ER so that families are not too worried about the situation that is happening. In addition, the main fact that must be improved is the quality of services in the ER that needs to be improved through efforts to improve human resources, facilities, procedures, services and other technical aspects.

\section{CONCLUSIONS}

Most respondents get response time in the right category, which is 21 respondents (63.6\%) and Most respondents had an anxiety level in the moderate category, namely 17 respondents $(51.5 \%)$. There is a relationship between response time handling of stroke patients with anxiety in the patient's family in the Emergency Room of Luwuk Regional Hospital $(p$-value $=0,000<\langle=0.05)$

\section{REFERENCES}

Bethesda, 2014. Melanjutkan Hidup Pasca Stroke. http://www.strokebethesda.com/index2.php?option=com_content\&do_pdf=1\& id=229. Tanggal 7 Februari, jam 10.30 WIB.

Capernito, Lynda J, 2015. Diagnosa Keperawatan Aplikasi pada Praktik Klinis. Jakarta : EGC

Festy, P. 2012. Peran Keluarga Dalam Pelaksanaan Rehabilitasi Medik Pada Pasien Stroke. Jurnal Penelitian Fakultas Ilmu Kesehatan Universitas Muhammadiyah Surabaya.

Hadari, 2016. Instrumen Penelitian Bidang Social. Yogyakarta. Gajah Mada University Press.

Hamsyah, A, 2014. Warta Pengendalian Penyakit Tidak Menular. Jakarta: Depkes RI.

Hawari, Dadang, 2011. Manajemen Stres Cemas \& Depresi. Jakarta : Fakultas Kedokteran Universitas Indonesia.

Junaidi, Isakandar, 2011. Stroke: Waspada Ancamannya. Yogyakarta: Andi.

Pambudi, H. 2016.. Studi Fenomologis Kecemasan Keluarga Pada Pasien Stroke Yang Dirawat Di Ruang HND Santo Lukas RS Santa Elisabeth Semarang. Artikel Penelitian Fakultas Kedokteran UNDIP. 


\section{Journal Of Nursing Practice}

http://thejnp.org

Pudiastuti, R.D, 2015. Penyakit Pemicu Stroke. Yogyakarta: Nuha Medika

Ramaiah, S, 2015. Kecemasan Bagaimana Mengatasi Penyebabnya. Jakarta: Pustaka Popular Obor.

Ritarwan, K, 2013. Pengaruh Suhu Tubuh Terhadap Outcome Penderita Stroke yang Di Rawat Di RSUP H. Adam Malik Medan. Jurnal Penelitian Fakultas Kesehatan Universitas Sumetera Utara.

Setiadi, 2015. Keperawatan Keluarga. Jakarta: EGC.

Stuart, G.W, 2016. Buku Saku Keperawatan Jiwa. Jakarta: EGC.

Sugiyono, 2010. Statistika Untuk Penelitian. Bandung : Alfabeta.

WHO. 2017, Prevalence of Stroke and Transient Ischaemic Attack in the Elderly Population. http://www.who.int/infobase/report. Tanggal 2 Februari 2013, Jam $09.00 \mathrm{WIB}$.

Wihastuti, T.A, 2013. Hubungan Antara Dukungan Keluarga Dengan Tingkat Kecemasan Pada Pasien Pre Operasi Appendictomy Di Ruang Flamboyan Rsud Tarakan Pemerintah Provinsi Kalimantan Timur. Artikel Penelitian Fakultas Keperawatan Brawijaya.

Wright \& Leahey, 2012. Nursing and familles ; a guide to family assessment and intervension. Phyladelphia. Davis Company.

Yastroki. 2011. Masyarakat Perlu Disadarkan Untuk Penanggulangan Stroke. http://www.yastroki.or.id/read.php?id=349. Tanggal 22 Februari 2018, Jam $08.00 \mathrm{WIB}$

Yunitasari, P. 2012. Hubungan Jenis CVA dengan Kecemasan Keluarga Pasien CVA di RSSA Kota Malang. Jurnal Penelitian FK UM Malang 